\title{
Antimicrobial and Genotoxicity Effects of Zero-valent Iron Nanoparticles
}

\author{
Elham Barzan ${ }^{1}$; Sedigheh Mehrabian ${ }^{2}$; Saeed Irian ${ }^{2, *}$ \\ ${ }^{1}$ Department of Microbiology, Faculty of Science, Urmia Azad University, Urmia, IR Iran \\ ${ }^{2}$ Department of Cell and Molecular Biology, Faculty of Biological Sciences, Kharazmi University, Tehran, IR Iran \\ ${ }^{*}$ Corresponding author: Saeed Irian, Department of Cell and Molecular Biology, Faculty of Biological Sciences, Kharazmi University, Tehran, IR Iran. Tel: +98-2188329220, E-mail: \\ irian@tmu.ac.ir, aryanairian2003@yahoo.com
}

Received: January 22, 2013; Revised: May 5, 2013; Accepted: May 11, 2013

\begin{abstract}
Background: In a world of nanotechnology, the first concern is the potential environmental impact of nanoparticles. An efficient way to estimate nanotoxicity is to monitor the responses of bacteria exposed to these particles.

Objectives: The current study explored the antimicrobial properties of nZVI (zero-valent Iron nanoparticles) on the Gram-negative bacterial systems Erwinia amylovora, Xanthomonas oryzae and the Gram-positive bacterial systems Bacillus cereus and Streptomyces spp. The genotoxicity potential of nZVI was also assayed.

Materials and Methods: The toxicity of nZVI was tested by two different methods: Growing bacteria in liquid (broth dilution) and agar media (challenge test) containing different nZVI concentrations for 24-72 hours. The genotoxicity of nZVI was assessed using the preincubation version of the Ames test.

Results: The lowest concentrations of nZVI that inhibited the visible growth (MIC) of E. amylovora, X. oryzae, B. cereus and Streptomyces spp. were 625, 550,1250 and 1280 ppm, respectively. The minimum bactericidal concentration (MBC) for E. amylovora and X. oryzae were 10,000 and 5,000 ppm of nZVI, respectively. MBC was not observed for the Gram positive bacteria. No bacteriostatic and bactericidal effects were observed for oxidized nZVI. Mutant frequency did not increase according to the vehicle control at the concentrations assayed, indicating a lack of mutagenicity associated with nZVI.

Conclusions: nZVI nanoparticles are not mutagenic at low concentrations, therefore they can be used without detrimental effects on soil bacteria.
\end{abstract}

Keywords:Nanoparticles; Bronchial Provocation Tests; Mutagenicity

\section{Background}

Nanotechnology is a new and rapidly growing scientific field. Recent advances in this field have resulted in the production of different kinds of metal and metal oxide nanoparticles with antibacterial effects (1). These are particles with an average dimension range of 1-100 $\mathrm{nm}(2)$, and are divided into three groups of natural, incidental, and engineered nanoparticles (3). An important property of these particles is their greater surface area which is reflected by their increased reactivity (4). Nanomaterials have had several industrial applications in the production of commercial products in the areas of cosmetics, health, clothing, electrical, agriculture and even food and medicine (5).

The search for a simple, inexpensive and efficient method of eliminating contaminations has drawn a great deal of attention to iron nanoparticles. In 1996, zero-valent iron nanoparticles (nZVI) were introduced as an environmental remediation agent. Later, two different groups used nZVI in the permeable reactive barrier (PRB) technology $(6,7)$. PRB technology, which makes use of zero- valent iron, has been used for underground water remediation for more than 20 years (8). nZVI with an average dimension range of $50-300 \mathrm{~nm}$ and highly reactive is presently being used for environmental remediation (9). Iron nanoparticles, which are highly reactive and quickly oxidized by oxygen, are also being used for environmental remediation of heavy metals such as cadmium, mercury, silver and nickel, as well as chlorine, in particular in soil and water remediation (7). It has been shown that nZVI is capable of eliminating pesticides such as DDT and Lindane in addition to inorganic ions such as dichromate, arsenic, perchlorate and nitrate (10). Synthesis of $n Z V I$ is a relatively simple procedure and can be obtained by $\mathrm{Fe}^{3+}$ reacting with sodium borohydride in an aqueous solution (11).

$$
4 \mathrm{Fe}^{3+}+3 \mathrm{BH}^{4-}+9 \mathrm{H}_{2} \mathrm{O} \rightarrow 4 \mathrm{Fe}^{0}+3 \mathrm{H}_{2} \mathrm{BO}^{3-}+12 \mathrm{H}^{+}+6 \mathrm{H}_{2}
$$

Man is surrounded by a variety of carcinogens present in the environment. These agents by inducing changes in the sequence of the genetic material (mutation) may cause cancer. Hence, the identification of such mutagens 
is an important first step in improving human health, in particular, if they result in germ line mutations which can be inherited through generations. To this end, improving inexpensive, quick and simple methodologies to identify potential mutagens are of great health value (12). One such methodology makes use of bacteria, mainly due to their great rate of proliferation and other chemical and genetic properties. To date, there are several bacterial strains known to show sensitivity to a wide range of mutagens (13). In addition, the inability to synthesize cytochrome P450 mediated products makes them suitable for the analysis of potential mutagens (14).

A well established method of determining the potential mutagenic nature of a substance in a bacterial system is the Ames test which uses different strains of Salmonella typhimurium. Each of these strains carries a specific mutation in its histidine operon, and thus is incapable of synthesizing the amino acid histidine (His), whereas the wild type strain is prototroph $\left(\mathrm{His}^{+}\right)$, and can do so when provided with ammonium phosphate and a suitable carbon source such as glucose. Strains of S. typhimurium used in the Ames test are auxotroph (His ${ }^{-}$), and when grown in solid media containing a minimum amount of histidine along with a potential mutagen, only the bacteria with a reverse mutation in the His gene (revertants) are capable of growth and colony formation. Therefore, the Ames test operates by assaying for the presence of revertants, and its accuracy in detecting potential mutagens has been demonstrated $(14,15)$. In addition to His auxotrphy, the TA100 strain carries both $r f a$ and $u v r B-b i o$ mutations. The rfa mutation changes the properties of the bacterial cell wall by resulting in a defective lipopolysaccharide (LPS) layer that coats the bacterial surface, making the bacteria more permeable to larger molecules, while the uvrB-bio mutation makes the strain sensitive to UV light (unable to repair damaged DNA) and confers a biotin auxotrophy. Finally, this strain carries a mutation that enhances Rfactor plasmid pKM101 activity which confers ampicillin resistance (16).

\section{Objectives}

The present study investigated the antimicrobial effect of nZVI on four different agricultural soil bacteria, and its anti-mutagenic effect using the Ames test.

\section{Materials and Methods}

\subsection{Nanoparticles, Chemicals and Bacterial Strains}

nZVI with dimensions of 20-50 nm were provided in a black color non-homogenate solution by Pasargad Lotus Nanochemical Company (Iran). All other chemicals were purchased from Merck (Germany). Bacterial strains Erwinia amylovora, Xantomonas oryzae, Bacillus cereus and Streptomyces spp. were provide by the University of Jihad Agricultural Research (Tehran-Iran), and stored at $4^{\circ} \mathrm{C}$.
S. typhimurium TA100 was kindly provided by Professor Ames and stored at $-80^{\circ} \mathrm{C}$.

\subsection{Determining the Minimum Inhibitory Concen- tration}

To determine the minimum concentration of nZVI causing bacterial growth inhibition, tubes containing $1 \mathrm{~mL}$ of Mueller Hinton Broth for the three bacterial strains E. amylovora, X. oryzae and B. cereus, and a tube containing $1 \mathrm{~mL}$ of Sabouraud dextrose broth for Streptomyces spp. were initially prepared. Then, $1 \mathrm{~mL}$ of different concentrations of nZVI (1000-10000 ppm) was added to the tube containing $1 \mathrm{~mL}$ of a bacterial culture, followed by a 12 serial dilution to the total of 13 samples. These cultures for the three bacterial strains E. amylovora, $X$. oryzae and B. cereus were incubated at $28-30^{\circ} \mathrm{C}$, while those of Streptomyces spp. were incubated at $37^{\circ} \mathrm{C}$ in a shaking incubator. MIC was then determined for each tube in 24 hours intervals.

\subsection{Determining the Minimum Bacterial Concen- tration}

To determine the minimum concentration of nZVI causing bacterial death, following the preparation of Mueller Hinton Agar plates for bacterial strains E. amylovora, $X$. oryzae B. cereus, and Sabouraud dextrose agar plates for Streptomyces spp., several microliters of the samples before and after the MIC sample was inoculated onto these plates. These plates were incubated at the optimum growth conditions, specified for each bacterium. MBC was then determined for plates lacking bacterial growth.

\subsection{Challenge Test}

The test aimed to determine bacterial growth, or lack of growth in the presence of different concentrations of nZVI. For this purpose, $100 \mu \mathrm{L}$ of each of the nZVI dilutions was added to $100 \mu \mathrm{L}$ of a bacterial culture, separately. These mixtures were then added to $3 \mathrm{~mL}$ of $\mathrm{NaCl}$-containing top agar, and spread on the appropriate agar plates. These plates were incubated at the optimum growth conditions, specified for each bacterium.

\subsection{Confirmation of S. typhimurium TA100 Genotype}

Prior to performing the anti-mutagenic assay, S. typhimurium TA100 mutation was confirmed. The strain was grown on a nutrient agar plate, and the genotype was checked routinely for its histidine auxotrophy, deep rough ( $r f a)$ character, UV sensitivity ( $u v r B$ mutation,) and the presence of the R factor plasmid. Samples were stored at $-80^{\circ} \mathrm{C}$. This strain requires histidine to grow, and in the absence of an external histidine source, cells cannot grow to form colonies. The presence of the $u v r B$ mutation makes the strain sensitive to UV light. The rfa mutation changes the properties of the bacterial cell wall and causes a defective lipopolysaccharide (LPS) layer that coats the bacterial surface, making the bacteria more perme- 
able to larger molecules. The rfa mutation is indicated by sensitivity to crystal violet. The presence of $\mathrm{R}$ factor plasmid in this strain shows that they are resistant to ampicillin (14-16).

\subsection{Confirmation of the Appropriate Concentration of $n Z V I$ for the Ames Test}

S. typhimurium TA100 was cultured in the presence of different concentrations of nZVI. This assay also included positive (bacteria without nZVI) and negative (nZVI without bacteria) controls.

\subsection{Mutagenicity Assay Using S. typhimurium TA100}

In the first stage of the assay, $0.1 \mathrm{~mL}$ of the test material (i.e. nZVI) was added to $0.1 \mathrm{~mL}$ of a fresh overnight (16 hours) $S$. typhimurium TA100 culture at a concentration of $1 \times 10^{9} \mathrm{CFU} /$ $\mathrm{ml}$, followed by the addition of $0.1 \mathrm{~mL}$ of histidine-biotin solution in a sterilized top agar-containing tube. This tube was then mixed on a shaker for three seconds, and evenly spread on an agar plate containing minimal medium, in duplicates. The plates were incubated at $37^{\circ} \mathrm{C}$ for 48 hours. Positive and negative controls were also included in the assay. The negative control contained bacteria, a histidine-biotin solution and $\mathrm{ddH}_{2} \mathrm{O}$, and it was used for the purpose of monitoring the rate of spontaneous mutations. The positive control included bacteria, a histidine-biotin solution and the well known mutagen, sodium azide. These were also plated on agar plates containing glucose and minimal medium, and the plates were incubated at $37^{\circ} \mathrm{C}$ for 48 hours. Following the incubation, the number of revertant colonies was counted in all plates.

Mutagenicity was determined on the basis of $\mathrm{Q}_{\mathrm{m}}$ value that is the ratio of the number of revertant colonies in the test plates to those of the negative control. $\mathrm{A}_{\mathrm{m}}$ value of $\geq 2$ is indicative of a mutagen, while a value of 1.7 to 1.9 indicates a potential mutagen and a value of $\leq 1.6$ is considered nonmutagenic $(17,18)$.

\section{Results}

\subsection{MIC and MBC Tests}

MIC and MBC results for both nZVI and oxidized nZVI have been provided in Table 1 . These results indicated that nZVI, at certain concentrations, inhibited bacterial growth, while oxidized nZVI did not do so at any of the nZVI concentrations.

\subsection{Challenge Test}

Results on the growth of the contents of MIC tubes on agar plates (challenge test) indicated that nZVI at concentrations of $1000 \mathrm{ppm}$ and $5000 \mathrm{ppm}$ inhibited the growth of E. amylovora and X. oryzae, respectively. While no such growth inhibition was detected for $B$. cereus and Streptomyces spp. at any of the nZVI concentrations. Finally, no bacteriostatic or bactericidal effect was detected for oxidized nZVI at any of the nZVI concentrations (Figure 1).

\subsection{Mutagenicity Assay}

Results of S. typhimurium TA100 genotype confirmation are provided in Table 2, and the appropriate concentration of nZVI for the Ames test was determined at 1000ppm. Results of nZVI mutagenicity have been provided in Table 3. As indicated in Table 3, nZVI does not possess a significant $(P=99 \%)$ mutagenicity effect when compared to the negative control.

\section{Discussion}

Results of the challenge test for the bacteria E. amylovora and X. oryzae in the presence of nZVI showed the growth inhibition. Bacteriocidic effect was also detected at higher nZVI concentrations (>5000 ppm) for the two strains. In the current investigation, concentration of the nanoparticle appeared to have an important role in bacterial inactivation, a finding that is in line with the other reports (19-21). B. cereus and Streptomyces showed a greater resistance to nZVI compared to Gram-negative bacteria, and growth inhibition was observed, while no bactericidal effect was detected. This may be explained by the presence of the thick $(20-80 \mathrm{~nm})$ peptidoglycan layer in the cell walls of Gram positive bacteria, making them more resistant to the nanoparticle (22).

Table 1. Comparison of MIC and MBC Values for Zero-valent Iron Nanoparticle (nZVI) and Oxidized nZVI a, b

\begin{tabular}{|c|c|c|c|c|}
\hline \multirow[t]{2}{*}{ Bacteria } & \multicolumn{2}{|c|}{ nZVI, ppm } & \multicolumn{2}{|c|}{ Oxidized nZVI, ppm/mL } \\
\hline & MIC & MBC & MIC & MBC \\
\hline Erwinia amylovorac & 625 & 10000 & - & - \\
\hline Xantomonas oryzaec & 550 & 5000 & - & - \\
\hline Bacillus cereusc & 1250 & - & - & - \\
\hline Streptomyces spp. & 1280 & - & - & - \\
\hline
\end{tabular}


Figure 1. Comparison of Bacterial Growth in the Presence of Different Concentrations of Zero-valent Iron Nanoparticle (nZVI) and Oxidized nZVI With Those of the Control
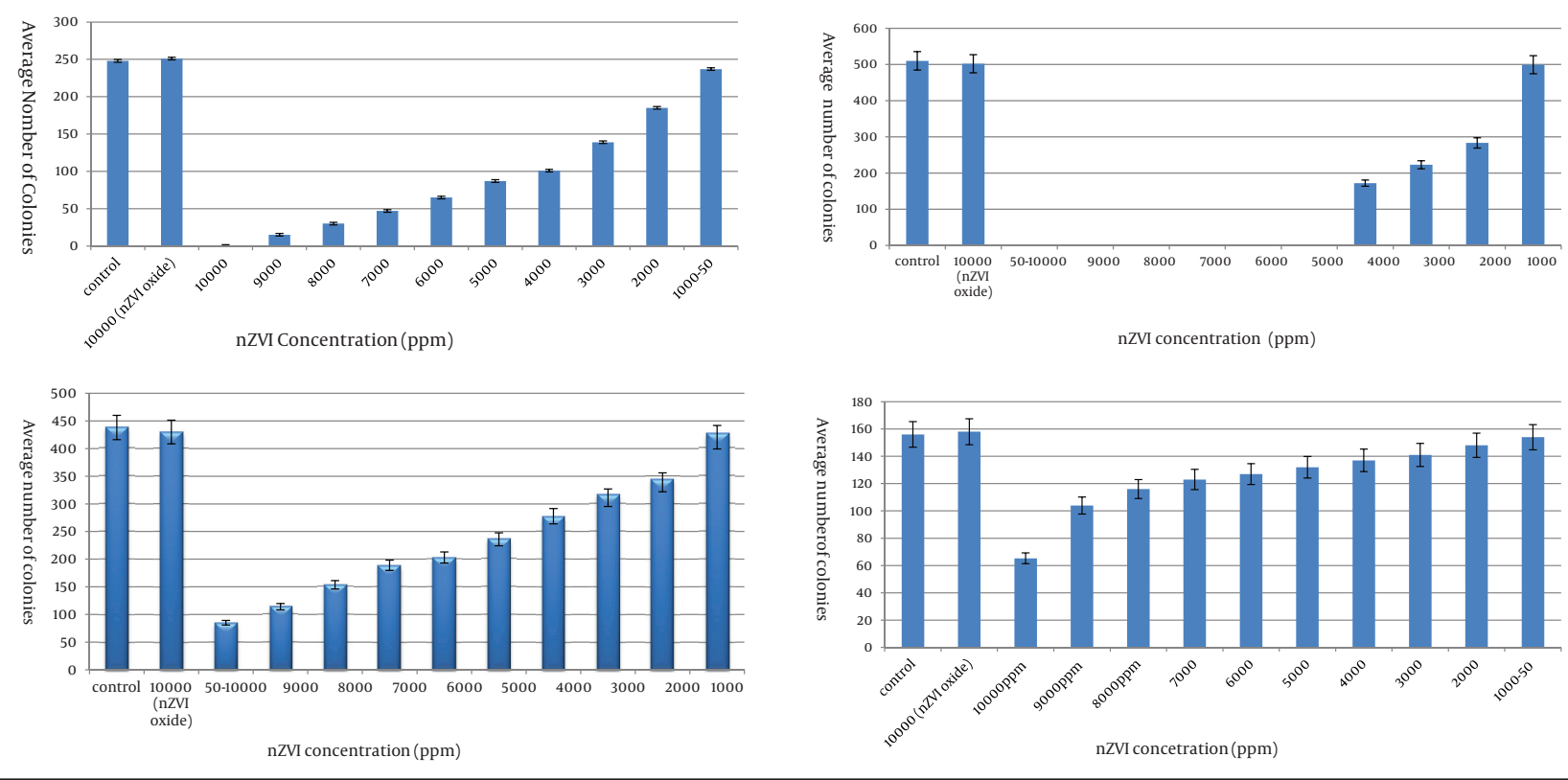

A. Erwinia amylovora; B. Xantomonas oryzae. C. Bacillus cereus. D. Streptomyces spp.

Table 2. Results of S. typhimurium TA100 Genotype Confirmation

\begin{tabular}{|c|c|c|c|}
\hline \multirow[t]{2}{*}{ Bacteria } & \multicolumn{3}{|c|}{ Genotype } \\
\hline & R-factor ${ }^{a}$ & uvrB Mutation ${ }^{b}$ & rfa Mutation \\
\hline S. typhimurium TA100 & + & + & + \\
\hline
\end{tabular}

Table 3. Results of the Mutagenic Effect of Zero-valent Iron Nanoparticle ${ }^{\text {a }}$

\begin{tabular}{lc}
\hline Samples & Number of S. typhimurium TA100 Revertant Colonies \\
\hline Negative control (ddH $\mathbf{2})$ & $10 \pm 0.577$ \\
Positive control (sodium azide) & $411 \pm 34.18$ \\
nZVI & $11 \pm 1.2$ \\
\hline
\end{tabular}

a Data are presented in Mean \pm SE.

The underlying mechanism of nZVI cytotoxicity is still a matter of debate (23). Researches have shown that a direct nZVI-cell contact has an important role in nZVI cytotoxicity $(24,25)$. The most important mechanism underlying the bactericidal effect of antibiotics and other drugs is the induction of oxidative stress through generation of reactive oxygen species (ROS) (26) such as superoxide $\left(\mathrm{O}_{2} \bullet^{-}\right)$, hydroxyl radicals $(\mathrm{OH} \bullet)$ and hydrogen peroxide that eventually lead to cellular protein and DNA damage (27). Park et al. (2009) demonstrated a ROSmediated bactericidal effect of silver nanoparticles (28). Lee et al. (2008) concluded that $E$. coli inactivation in the presence of nZVI might be mediated by the penetration of particles with an average dimension of 10-80 nm through the cell wall, followed by their interaction with the intracellular oxygen, resulting in oxidative stress and eventually bacterial cell death (1). Therefore, it is likely that such a mechanism may also be operating during the cytotoxic effect of nZVI with an average dimension of $20-50 \mathrm{~nm}$ used in the present investigation. The oxidized nZVI used in the current study did show a sign of bactericidal effect towards the tested bacterial strains. A reduction in the bactericidal effect of nZVI, following its oxidation, has been attributed to the formation 
of an oxidized iron layer on the nanoparticle (1). It is noteworthy that the black color of nZVI turns yellow, following oxidation (29). The important role played by the concentration of nanoparticles in their bacteriostatic and bactericidal effect, observed in this study, has also been reported by the others working on the antibacterial effects of silver and ZnO nanoparticles (19, 21). The Ames test has long been used as an accurate method to identify potential mutagens, in such a way that over $70 \%$ of the mutagens identified thus far have used Salmonella spp. (30). In the present study, using S. typhimurium TA100, nZVI at a concentration of $1000 \mathrm{ppm}$ showed to have no mutagenic effect. This concentration of nZVI, however, did not have any antibacterial effects towards S. typhimurium TA100. The Ames test has also shown that the iron oxide nanoparticles have no mutagenic effect (31). Similar results have been observed by the others analyzing the in vivo genotoxicity effect of silver nanoparticles (32). nZVI nanoparticles are not mutagenic at low concentrations, and hence can be used without any detrimental effects on soil bacteria.

\section{Acknowledgements}

There is no Acknowledgements.

\section{Authors' Contribution}

None declared.

\section{Financial Disclosure}

There is no financial disclosure.

\section{Funding/Support}

There is no Funding/Support.

\section{References}

1. Lee C, Kim JY, Lee WI, Nelson KL, Yoon J, Sedlak DL. Bactericidal effect of zero-valent iron nanoparticles on Escherichia coli. Environ Sci Technol. 2008;42(13):4927-33.

2. Nanotechnologies-Terminology and definitions for nano-objectsNanoparticle, nanofibre and nanoplate: International Organization for Standardization.; 2008.

3. Keane E. . Fate, transport and toxicity of nanoscale zero-valent iron (nZVI) used during superfund remediation.. : Duke University; 2010.

4. Tratnyek PG, Johnson RL. Nanotechnologies for environmental cleanup. Nano Today. 2006;1(2):44-8.

5. Nowack B, Bucheli TD. Occurrence, behavior and effects of nanoparticles in the environment. Environ Pollut. 2007;150(1):522 .

6. Kumar CSSR. Nanomaterials -Toxicity, Health and Environmental Issues.Weinheim, Germany:WILEY-VCH; 2006.

7. Zhang WX, Elliott DW. Applications of iron nanoparticles for groundwater remediation. Remediat J. 2006;16(2):7-21.

8. Senzaki T, Kumagai Y. Removal of chlorinated organic compounds from wastewater by reduction process: Treatment of 1, 1, 2, 2-tetrachloroethane with iron powder. Kogyo Yosui. $1988 ; 357(2): 2-7$
9. Müller NC, Nowack B. Nano zero valent iron-The solution for water and soil remediation. Rep Observatory NANO. 2010:1-34.

10. Zhang WX. Nanoscale Iron Particles for Environmental Remediation: An Overview. J Nanopart Res. 2003;5(3-4):323-32.

11. Wang $\mathrm{CB}$, Zhang WX. Synthesizing nanoscale iron particles for rapid and complete dechlorination of TCE and PCBs. Environ Sci Tech. 1997;31(7):2154-6.

12. Wessner DR, Maiorano PC, Kenyon J, Pillsbury R, Campbell AM. Spot- overlay Ames test of potential mutagens. 2000. Available from: http://www.zoo.utoronto.ca/able.

13. Mortelmans K, Zeiger E. The Ames Salmonella/microsome mutagenicity assay. Mutat Res. 2000;455(1-2):29-60.

14. Ames BN, Durston WE, Yamasaki E, Lee FD. Carcinogens are mutagens: a simple test system combining liver homogenates for activation and bacteria for detection. Proc Natl Acad Sci U S A. 1973;70(8):2281-5

15. Ames BN, McCann J, Yamasaki E. Methods for detecting carcinogens and mutagens with the Salmonella/mammalian-microsome mutagenicity test. Mutat Res. 1975;31(6):347-64.

16. Maron DM, Ames BN. Revised methods for the Salmonella mutagenicity test. Mutat Res. 1983;113(3-4):173-215.

17. Krebsfaenger N. Ames test: Bacterial Reverse Mutation Assay. 2010 Available from: www.genpharmtox.com.

18. Opašić L, Zajc M, Virapin C, Petelin E, Stafa A. The Ames mutagenicity testing - mutations in reverse gea. 2006. Available from: ww.astro.hr/s3/izvjestaji/s3pp2009/WebReport-AmesTest.pdf.

19. Kim JS, Kuk E, Yu KN, Kim JH, Park SJ, Lee HJ, et al. Antimicrobial effects of silver nanoparticles. Nanomedicine. 2007;3(1):95-101.

20. Taylor EN, Webster T]. The use of superparamagnetic nanoparticles for prosthetic biofilm prevention. Int J Nanomedicine. 2009;4:145-52.

21. Zhang L, Jiang Y, Ding Y, Povey M, York D. Investigation into the antibacterial behaviour of suspensions of $\mathrm{ZnO}$ nanoparticles (ZnO nanofluids).J Nanopart Res. 2007;9(3):479-89.

22. Olapade OA, Depas MM, Jensen ET, McLellan SL. Microbial communities and fecal indicator bacteria associated with Cladophora mats on beach sites along Lake Michigan shores. Appl Environ Microbiol. 2006;72(3):1932-8.

23. Nel AE, Madler L, Velegol D, Xia T, Hoek EM, Somasundaran P, et al. Understanding biophysicochemical interactions at the nano-bio interface. Nat Mater. 2009;8(7):543-57.

24. Auffan M, Achouak W, Rose J, Roncato MA, Chaneac C, Waite DT, et al. Relation between the redox state of iron-based nanoparticles and their cytotoxicity toward Escherichia coli. Environ Sci Technol. 2008;42(17):6730-5

25. Xiu ZM, Gregory KB, Lowry GV, Alvarez PI. Effect of bare and coated nanoscale zerovalent iron on tceA and vcrA gene expression in Dehalococcoides spp. Environ Sci Technol. 2010;44(19):7647-51.

26. Kohanski MA, Dwyer DJ, Hayete B, Lawrence CA, Collins JJ. A common mechanism of cellular death induced by bactericidal antibiotics. Cell. 2007;130(5):797-810.

27. Sies H. Oxidative stress: oxidants and antioxidants. Exp Physiol. 1997;82(2):291-5.

28. Park HJ, Kim JY, Kim J, Lee JH, Hahn JS, Gu MB, et al. Silver-ion-mediated reactive oxygen species generation affecting bactericidal activity. Water Res. 2009;43(4):1027-32.

29. Davenport AJ, Oblonsky LJ, Ryan MP, Toney MF. The structure of the passive film that forms on iron in aqueous environments. $J$ Electrochem Soc. 2000;147(6):2162-73.

30. Zeiger E, Ashby J, Bakale G, Enslein K, Klopman G, Rosenkranz HS. Prediction of Salmonella mutagenicity. Mutagenesis. 1996;11(5):471-84.

31. Szalay B. Iron oxide nanoparticles and their toxicological effects: in vivo and in vitro studies: szte; 2012

32. Kim JS, Sung JH, Ji JH, Song KS, Lee JH, Kang CS, et al. In vivo Genotoxicity of Silver Nanoparticles after 90-day Silver Nanoparticle Inhalation Exposure. Saf Health Work. 2011;2(1):34-8. 